\title{
Peningkatan Kemampuan Menulis Teks Diskusi Menggunakan Model Kooperatif Learning Tipe Debat Pada Siswa Kelas VIII H SMP Negeri 1 Rejang Lebong
}

\author{
Efnawarty \\ SMPN 1 Rejang Lebong \\ "E-mail: efnawartyef@yahoo.co.id
}

\begin{abstract}
Abstrak
Tujuan penelitian ini untuk mengetahui peningkatan kemampuan siswa dalam menulis teks diskusi pada siswa kelas VIII H SMP Negeri 1 Rejang Lebong dengan menggunakan model kooperatif learning tipe debat. Penelitian ini merupakan penelitian tindakan kelas yang terdiri dari dua siklus. Setiap siklus terdiri dari perencanaan, pelaksanaan, pengamatan dan refleksi. Teknik pengumpulan datanya menggunakan teknik tes yaitu menulis teks diskusi, dan observasi kegiatan guru dan siswa ketika debat berlangsung dalam pembelajaran serta hasil menulis teks siswa. Hasil penelitian menunjukkan bahwa terjadi peningkatan kemampuan siswa dalam menulis teks diskusi yang disertai argumen dan data yang akurat. Hal ini dapat dilihat dari nilai rata-rata siswa pada siklus I sebesar 68,59 dengan kategori cukup, meningkat menjadi 77,74 pada siklus II dengan kategori baik. Selain itu, penggunaan model ini dapat meningkatkan aktiftas siswa dalam berdebat untuk mencari data dan fakta akurat, yang akan dijadikan sebagai bahan dalam menulis teks diskusi.
\end{abstract}

Kata kunci: Menulis, Teks Diskusi, Debat.

\section{PENDAHULUAN}

Mata pelajaran Bahasa Indonesia memiliki peranan yang sangat penting dalam kehidupan sehari-hari, baik untuk berkomunikasi lisan maupun untuk berkomunikasi tulisan. Apalagi dalam Kurikulum 2013 mata pelajaran bahasa Indonesia memegang peran utama sebagai penghela ilmu pengetahuan. Oleh karena itu, diperlukan pengembangkan kemampuan siswa dalam berpikir kritis, logis, dan kreatif, serta inovatif agar peran bahasa Indonesia sebagai penghela ilmu pengetahuan tersebut terus berkembang. Untuk itulah pembelajaran Bahasa Indonesia selalu diarahkan untuk meningkatkan kemampuan siswa dalam berkomunikasi baik secara lisan maupun tulisan, yang mencakup aspek keterampilan berbahasa.

Menurut Tarigan (1982:1) keterampilan berbahasa itu mencakup keterampilan menyimak, berbicara, membaca, dan menulis. Menulis merupakan salah satu keterampilan berbahasa yang dipergunakan dalam komunikasi secara tidak langsung. Keterampilan menulis tersebut tidak didapatkan secara alamiah, tetapi merupakan hasil dari poses pembelajaran dan ketekunan dalam berlatihkarena menulis merupakan suatu proses.Disamping sebagai proses, menulis juga merupakan suatu kegiatan yang kompleks. Sebagaimana diungkapkan Suddhono dan Slamet (2014: 153), bahwa kegiatan menulis merupakan kegiatan yang sangat kompleks karena melibatkan cara berpikir yang teratur dan berbagai persyaratan yang berkaitan dengan teknik penulisan, antara lain (1) adanya kesatuan gagasan, (2) penggunaan kalimat yang jelas dan efektif, (3) paragraf disusun dengan baik, (4) penerapan kaidah ejaan yang benar, dan (5) penguasaan kosa kata yang memadai. Selain itu, dalam kegiatan menulis selalu menghasilkan tulisan berupa ide atau gagasan yang ingin disampaikan oleh penulis kepada orang lain. Untuk dapat menyampaikan idenya tersebut diperlukan tahap berfikir kritis, agar ide yang disampaikan komunikatif. Selain itu, dalam kegiatan menulis, penulis harus terampil memanfaatkan grafologi, struktur bahasa, dan kosa kata (Tarigan, 1982:3).

Pembelajaran menulis pada kurikulum 2013 khususnya kelas VIII, dipelajari berbagai jenis teks, salah satunya adalah teks diskusi. Menurut Ahmad (2017: 1) teks diskusi adalah teks yang 
memaparkan dua hal yang berbeda atau pro dan kontra antara dua belah pihak yang mana kemudian keduanya saling membicarakan hal tersebut untuk dapat memperoleh informasi tertentu. Senada dengan pendapat di atas, Amri (2017: 1) Teks diskusi adalah salah satu jenis teks yang memberikan dua pendapat mengenai suatu hal (pro dan kontra) yang menimbulkan kedua belah pihak menjadi saling membicarakan permasalahan yang sedang dipersoalkan (diskusi). Ciri esensial teks diskusi adalah adanya issu kontroversi yang menjadi pembicaraan hangat di tengah masyarakat. Hal inilah yang mendorong siswa untuk mendengarkan, menanggapi pendapat orang lain, dan mengajukan pertanyaan yang disertai dengan argumen yang jelas dan koheren.

Diskusi terlibat interaksi antar induvidu atau siswa yang saling mempengaruhi untuk mendapatkan suatu kesimpulan.Oleh karena itu, guru harus dapat mengarahkan pembelajaran yang menyenangkandengan memilihi model pembelajaran yang tepat.Salah satu model pembelajaran yang melibatkan interaksi antar siswa adalah model pembelajaran kooperatif learning. Ide utama pembelajaran kooperatif adalah siswa bekerja sama untuk belajar dan bertanggung jawab pada kemajuan belajar temannya. Seperti yang dikatakan oleh Komalasari (2011: 62) kerja sama dalam kelompok belajar tersebut terdiri dari 2-5 orang, dengan struktur kelompok yang bersifat heterogen.Adapun ciri-ciri pembelajaran kooperatif adalah:

Diskusi terlibat interaksi antar induvidu atau siswa yang saling mempengaruhi untuk mendapatkan suatu kesimpulan.Oleh karena itu, guru harus dapat mengarahkan pembelajaran yang menyenangkandengan memilihi model pembelajaran yang tepat.Salah satu model pembelajaran yang melibatkan interaksi antar siswa adalah model pembelajaran kooperatif learning. Ide utama pembelajaran kooperatif adalah siswa bekerja sama untuk belajar dan bertanggung jawab pada kemajuan belajar temannya. Seperti yang dikatakan oleh Komalasari (2011: 62) kerja sama dalam kelompok belajar tersebut terdiri dari 2-5 orang, dengan struktur kelompok yang bersifat heterogen.Adapun ciri-ciri pembelajaran kooperatif adalah:

Siswa bekerja dalam kelompok secara kooperatif untuk menuntaskan materi belajarnya.

Kelompok dibentuk dari siswa yang memiliki kemampuan tinggi, sedang, dan rendah.

Diarahkan anggota kelompok berasal dari ras, budaya, suku, dan jenis kelamin yang berbedabeda.

Penghargaan lebih berorientasi kelompok ketimbang individu.

Ciri-ciri di atas dapat ditekankan bahwa strategi pembelajaran kooperatif dikembangkan untuk mencapai hasil belajar, yaitu hasil berupa prestasi akademik, toleransi, menerima keragaman, dan pengembangan keterampilan sosial, Suprijono (2009: 61)

Untuk dapat mengaplikasi model pembelajaran kooperatif learning ini, dibutuhkan fase-fase tertentu, agar pembelajaran sesuai dengan tujuan yang diharapkan. Adapunn fase-fase tersebut menurut Shoimin (2014: 46) adalah:

\begin{tabular}{|l|l|l|}
\hline No & Fase-fase & \multicolumn{2}{|c|}{ Aktivitas Guru } \\
\hline 1. & $\begin{array}{l}\text { Menyampaikan tujuan dan } \\
\text { memotivasi siswa. }\end{array}$ & $\begin{array}{l}\text { Guru menyampaikan tujuan pelajaran } \\
\text { yang akan dicapai pada pelajaran tersebut dan } \\
\text { memotivasi siswa belajar. }\end{array}$ \\
\hline Menyajikan informasi & $\begin{array}{c}\text { Guru menyampaikan informasi kepada } \\
\text { siswa dengan jalan demonstrasi atau lewat } \\
\text { bahan bacaan. }\end{array}$ \\
\hline $\begin{array}{l}\text { Mengorganisasikan siswa } \\
\text { delam kelompok-kelompok }\end{array}$ & $\begin{array}{l}\text { Guru menjelaskan kepada siswa } \\
\text { bagaimana caranya membentuk kelompok } \\
\text { belajar dan membantu setiap kelompok agar } \\
\text { melakukan transisi secara efisien. }\end{array}$ \\
\hline $\begin{array}{l}\text { Membimbing kelompok } \\
\text { bekerja dan belajar }\end{array}$ & $\begin{array}{l}\text { Guru membimbing kelompok-kelompok } \\
\text { belajar pada saat mereka mengerjakan tugas- } \\
\text { tugasnya. }\end{array}$ \\
\hline
\end{tabular}




\begin{tabular}{|l|l|l|}
\hline Evaluasi & $\begin{array}{c}\text { Guru mengevaluasi hasil belajar tentang } \\
\text { materi yang telah dipelajari dan masing-masing } \\
\text { kelompok mempresentasikan hasil kerjanya }\end{array}$ \\
\hline Memberikan penghargaan & $\begin{array}{l}\text { Guru mencari cara-cara untuk } \\
\text { menghargai, baik upaya maupun hasil belajar } \\
\text { individu dan kelompok }\end{array}$ \\
\hline
\end{tabular}

Prosedur atau langkah-langkah pembelajaran kooperatif pada prinsipnya terdiri atas empat tahap, yaitu:

Penjelasan Materi, tahap ini merupakan tahapan penyampaian pokok-pokok materi pelajaran sebelum siswa belajar dalam kelompok. Tujuan utama tahapan ini adalah pemahaman siswa terhadap pokok materi pelajaran.

Kelompok belajar, tahapan ini dilakukan setelah guru memberikan penjelasan materi, siswa bekerja dalam kelompok yang telah dibentuk sebelumnya.

Penilaian, penilaian dalam pembelajaran kooperatif bisa dilakukan melalui tes atau kuis, yang dilakukan secara individu atau kelompok. Tes individu akan memberikan penilaian kemampuan individu, sedangkan kelompok akan memberikan penilaian pada kemampuan kelompoknya.

Pengakuan Tim, adalah penetapan tim yang dianggap paling menonjol atau tim paling berprestasi untuk kemudian diberikan penghargaan atau hadiah, dengan harapan dapat memotivasi tim untuk terus berprestasi lebih baik lagi.

Salah satu model pembelajaran kopertif learning adalah debat. Dalam debat siswa dilatih menyampaikan pendapat atau gagasan dan bagaimana mempertahankan pendapat yang disertai dengan bukti/data, fakta akurat, pengalaman penulis serta referensi yang berhubungan dengan isu yang dibahas. Selain itu, dalam debat juga dapat melatih siswa berfikir kritis dan logis serta melatih siswa bagaimana menghargai pendapat orang lain yang berseberangan dengannya. Materi yang disampaikan dalam debat adalah yang mengandung kontroversi dan menarik perhatian siswa, aktual dan terjadi di tengah masyarakat.

Untuk melaksanakan debat tersebut siswa dibagi menjadi dua kelompok yaitu kelompok pro (mendukung) dan kelompok kontra (menentang) kemudian mereja duduk yang berhadapan. Kemudian siswa membaca materi pelajaran yang menimbulkan kontroversi, materi pelajaran disusun menjadi dua paket yaitu paket pendukung (pro) dan paket penentang (kontra). Kemudian materi tersebut dicermati oleh masing-masing kelompok. Setelah itu, perwakilan kelompok pendukung menyampaikan argumennya dan dikomentari oleh kelompok penentang, begitu sebaliknya sampai ditemukan sejumlah informasi yang diinginkan. Setelah siswa saling beragumen kemudian hasil debat tersebut dipresentasikan oleh perwakilan salah satu kelompok, dan ditanggapi oleh kelompok lainnya. Kemudian ada bagian terakhir guru membimbing siswa membuat kesimpulan dan menambahkan materi pelajaran bila diperlukan

\section{Sintak/langkah-langkah model pembelajaran debat}

Sintak atau langkah-langkah model pembelajaran debat ini menurut Badriah (2015: 1) dapat dijelaskan sebagai berikut:

Guru membagi siswa menjadi 2 kelompok peserta debat, yang satu pro dan yang lainnya kontra dengan duduk berhadapan antar kelompok.

Guru memberikan tugas untuk membaca materi yang akan diperdebatkan oleh kedua kelompok di atas.

Setelah selesai membaca materi, Guru menunjuk salah satu anggota kelompok pro untuk berbicara saat itu, kemudian setelah selesai ditanggapi oleh kelompok kontra. Demikian seterusnya sampai sebagian besar siswa bisa mengemukakan pendapatnya.

Inti/ide-ide dari setiap pendapat atau pembicaraan di tulis di papan pendapat sampai 
mendapatkan sejumlah ide yang diharapkan.

Guru menambahkan konsep/ide yang belum terungkapkan.

Dari data-data yang diungkapkan tersebut, guru mengajak siswa membuat kesimpulan/rangkuman yang mengacu pada topik yang ingin dicapai.

Keterampilan menulis yang menggunakan model pembelajaran kooperatif learning dalam menulis teks puisi, merupakan keterampilan berbahasa yang penting dan harus dikuasai oleh siswa, karena menulis salah satu bagian dari penilaian keterampilan dan sangat menentukan keberhasilan siswa dalam pembelajaran. Dengan menulis siswa dapat menyampaikan ide atau gagasannya secara tertulis, menguasai potensi yang dimilikinya, dan dapat menyampaikan gagasan atau ide secara berurutan dan sistematis, serta dapat melatih diri untuk selalu berfikir kritis dan logis dan kreatif. Oleh karena itu, guru sebagai salah satu komponen penting dalam proses pembelajaran harus selalu melakukan pembinaan yang serius, efektif dan berkesinambungan, agar potensi yang dimiliki siswa berkembang optimal.

Kenyataan yang terjadi, siswa tidak terampil dalam menyampaikan atau mengkomukasikan idenya lewat tulisan dengan baik. Bahkan sebagian guru bahasa Indonesia, khususnya di SMPN 1 RejangLebong mengakui bahwa siswanya sangat sulit menguasai keterampilan menulis karena menulis merupakan salah satu tingkat kesulitan paling tinggi bagi siswa. Oleh karena itu, guru lebih banyak menggunakan metode ceramah dalam pembelajaran menulis sehingga tujuan pembelajaran tidak tercapai dengan semestinya. Agar siswa mampu menulis dengan baik, guru tidak hanya memberikan penyampaian materi tetapi juga memotivasi, membimbing dan mengarahkan siswa, serta menyampaikan pembelajaran yang menarik dan menyenangkan agar siswa terbiasa dan terampil menuangkan ide-idenya melaui media tulisan, sehigga diharapkan hasil pembelajaran mampu mencapai KKM yang telah ditetapkan.

Sekalipun keterampilan menulis merupakan keterampilan yang paling sulit bagi siswa, namun kurikulum mengharuskan siswa untuk terampil mengusai keterampilan tersebut tanpa mengabaikan keterampilan berbahsa yang lainnya. Untuk itu dalam kurikulum 2013, kelas VIII terdapat beberapa kompetensi dasar bahasa Indonesia yang mengharuskan siswa menguasai beberapa jenis keterampilan menulis, salah satu kompetansi menulis yang harus dikuasai oleh siswa tersebut adalah kompetensi dasar (KD 4.2). Kompetensi dasar tersebut berbunyi "Menyusun teks cerita moral/fabel, ulasan, diskusi, cerita prosedur, dan cerita biografi sesuai dengan karakteristik teks yang akan dibuat baik secara lisan maupun tulisan."

Pembelajaran kompetensi tersebut di SMP Negeri 1 Rejang Lebong, tidak berjalan dengan semestinya karena ditemukan bebarapa kendala, baik oleh guru maupun oleh siswa itu sendiri. Masalah kesulitan dalam pembelajaran menulis, khususnya menulis teks diskusi terlihat pada siswa kelas VIII H SMPN 1 Rejang Lebong. Berdasarkan hasil observasi dan diskusi dengan salah seorang guru bahasa Indonesia, ditemukan bahwa nilai rata-rata keterampilan menulis teks diskusidari 35 orang siswa adalah 64,38 sedangkan ketuntasan belajar menulis di SMP ini adalah 70,00. Siswa yang dikatakan tuntas sebanyak 4 orang, sisanya 31 orang belum tuntas. Hal ini menunjukkan bahwa pembelajaran keterampilan menulis teks diskusi siswa kelas VIII H masih jauh dari tujuan yang telah ditargetkan, karena nilai rata-ratanya di bawah KKM.

Beberapa kendala yang dialami siswa dalam pembelajaran menulis teks diskusi adalah: (1) kesulitan menyampaikan argumen yang didukung oleh bukti/data, fakta akurat, pengalaman penulis serta referensi yang berhubungan dengan isu yang dibahas, (2) arguman mendukung dan menentang yang dibuat siswa dalam menulis teks diskusi,kurang tepat dan kacau sehingga sulit dipahami, (3) guru belum menerapkan model pembelajaran yang tepat dalam proses pembelajaran agar menarik minat dan memudahkan siswa menulis teks diskusi.

Berdasarkan fenomena tersebut, maka perlu adanya alternatif pembelajaran yang dapat meningkatkan kemampuan menulis teks diskusi siswa. Oleh karena itu, menarik untuk dilakukan penelitian berupa penelitian tindakan kelas dengan harapan dapat meningkatkan kemampuan siswa 
dalam menulis, khususnya menulis teks diskusi, dengan judul "Peningkatan Kemampuan Menulis Teks Diskusi dengan Menggunakan Model Kooperatif Learning Tipe Debat pada Siswa Kelas VIII H SMP Negeri 1 Rejang Lebong."

\section{METODE/EKSPERIMEN}

Penelitian ini merupakan penelitian tindakan kelas (classroom action research) dengan model spiral dari Kemmis \& Mc Taggart.Penelitian dilaksanakan dengan dua silkus yang setiap siklus terdiri atas dua kali pertemuan. Setiap siklus dalam penelitian ini meliputi: perencanaan, pelaksanaan, pengamatan,dan refleksi.Lokasipenelitian adalah SMP Negeri 1 Rejang Lebong dengan subjek penelitian yaitu siswa kelas VIII H, yang berjumlah 35 orang yang terdiri dari 11 orang laki-laki dan 24 orang perempuan, tahun pelajaran 2016/2017. Data dikumpulkan dengan menggunakan lembar observasi siswa dan guru, serta teknik tes untuk menilai kemampuan siswa dalam menulis teks diskusi, yang dapat dilihat pada tabel berikut:

\section{Tabel 1}

Format Penilaian Kemampuan Menulis Teks Diskusi

\begin{tabular}{|c|l|c|}
\hline No & $\begin{array}{l}\text { Aspek Penilaian Kemampuan } \\
\text { Menulis Teks Diskusi }\end{array}$ & $\begin{array}{l}\text { Skor } \\
\text { Maksimal }\end{array}$ \\
\hline 1. & Isi Teks Diskusi & 30 \\
\hline 2. & Organisasi & 20 \\
\hline 3 & Kosa Kata & 20 \\
\hline 4 & Penggunaan Bahasa & 20 \\
\hline 5 & Mekanik & 10 \\
\hline & Jumlah & $\mathbf{1 0 0}$ \\
\hline
\end{tabular}

Tabel 2

Deskripsi Penilaian Menulis Teks Puisi

\begin{tabular}{|c|c|c|c|c|}
\hline 0 & $\begin{array}{c}\text { Aspek } \\
\text { Penilaian }\end{array}$ & $\begin{array}{r}\text { Ren } \\
\text { tang Skor }\end{array}$ & $\begin{array}{ll}\text { Kate } \\
\text { gori }\end{array}$ & Deskripsi \\
\hline & \multirow[t]{4}{*}{ Teks $^{\text {Isi }}$} & $27-$ & $\begin{array}{l}\text { Sang } \\
\text { at Baik - } \\
\text { Sempurna }\end{array}$ & $\begin{array}{l}\text { Menguasai topik tulisan, } \\
\text { substantif, pengembangan teks } \\
\text { observasi lengkap, dan relevan } \\
\text { dengan topik yang dibahas }\end{array}$ \\
\hline & & $22-$ & p Baik $^{\text {Cuku }}$ & \begin{tabular}{lr}
\multicolumn{1}{c}{ Cukup } & menguasai \\
permasalah- an, cukup memadai, & pengem-bangan observasi \\
terbatas, relevan dengan topik \\
namun kurang rinci
\end{tabular} \\
\hline & & $17-$ & $\begin{array}{r}\text { Seda } \\
\text { ng- Cukup }\end{array}$ & \begin{tabular}{l}
\multicolumn{3}{c}{ Penguasaan permasalahan } \\
terbatas, substansi kurang, \\
pengembangan topik tidak \\
memadai
\end{tabular} \\
\hline & & 13- & $\begin{array}{l}\text { Sang } \\
\text { at Kurang }\end{array}$ & $\begin{array}{l}\text { Tidak } \\
\text { menguasai } \\
\text { permasalah- an, tidak ada } \\
\text { substansi, tidak relevan, atau } \\
\text { tidak layak dinilai isu, argumen } \\
\text { mendukung, argumen menen- } \\
\text { tang, simpulan/saran }\end{array}$ \\
\hline & Organi & 18- & Sang & Ekspresi lancar, gagasan \\
\hline
\end{tabular}




\begin{tabular}{|c|c|c|c|c|}
\hline 0 & $\begin{array}{l}\text { Aspek } \\
\text { Penilaian }\end{array}$ & $\begin{array}{r}\text { Ren } \\
\text { tang Skor }\end{array}$ & gori & Deskripsi \\
\hline & \multirow[t]{4}{*}{ sasi } & 20 & $\begin{array}{l}\text { at Baik- } \\
\text { Sempurn }\end{array}$ & $\begin{array}{l}\text { diungkapkan dengan jelas, padat, } \\
\text { tertata dengan baik, urutan logis, } \\
\text { kohesif }\end{array}$ \\
\hline & & $14-$ & p Baik $^{\text {Cuku }}$ & $\begin{array}{l}\text { Kurang lancar, kurang ter- } \\
\text { organisasi tetapi ide utama } \\
\text { ternyatakan, pendukung terbatas, } \\
\text { logis tetapi tidak lengkap }\end{array}$ \\
\hline & & $10-$ & $\begin{array}{l}\text { Seda } \\
\text { ng Cukup }\end{array}$ & $\begin{array}{l}\text { Tidak lancar, gagasan } \\
\text { kacau atau tidak terkait, urutan } \\
\text { dan pengembangan kurang logis }\end{array}$ \\
\hline & & $7-9$ & $\begin{array}{l}\text { Sang } \\
\text { at Kurang }\end{array}$ & $\begin{array}{l}\text { Tidak komunikatif, tidak ter- } \\
\text { organisasi/tidak layak dinilai }\end{array}$ \\
\hline & \multirow[t]{4}{*}{ Kata } & $18-$ & $\begin{array}{l}\text { Sang } \\
\text { at Baik } \\
\text { Sem } \\
\text { purna }\end{array}$ & $\begin{array}{l}\text { Penguasaan kata canggih, } \\
\text { pilihan kata dan ungkapan efektif, } \\
\text { menguasai pemben-tukan kata, } \\
\text { penggunaan register tepat }\end{array}$ \\
\hline & & 14- & p Baik & $\begin{array}{l}\text { Penguasaan kata memadai, } \\
\text { pilihan, bentuk, dan penggunaan } \\
\text { kata/ungkapan kadangkadang } \\
\text { salah namun tidak mengganggu }\end{array}$ \\
\hline & & $10-$ & $\begin{array}{l}\text { Seda } \\
\text { ng-Cukup }\end{array}$ & $\begin{array}{l}\text { Penguasaan kata terbatas, } \\
\text { se-ring terjadi kesalahan bentuk, } \\
\text { pilihan, dan penggunaan kosa } \\
\text { kata/ungkapan, makna mem- } \\
\text { bingungkan atau tidak jelas }\end{array}$ \\
\hline & & $7-9$ & $\begin{array}{l}\text { Sang } \\
\text { at Kurang }\end{array}$ & 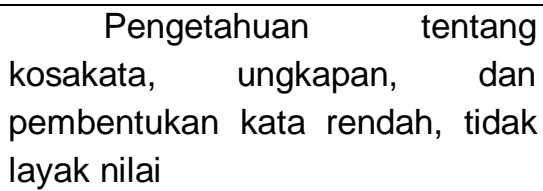 \\
\hline & \multirow[t]{3}{*}{$\begin{array}{l}\text { Pengg } \\
\text { unaan } \\
\text { Bahasa }\end{array}$} & $18-$ & $\begin{array}{l}\text { Sang } \\
\text { at Baik- } \\
\text { Sempurna }\end{array}$ & $\begin{array}{l}\text { Konstruksi kompleks dan } \\
\text { efektif, terdapat hanya sedikit } \\
\text { kesalahan penggunaan bahasa } \\
\text { (urutan/fungsi kata, artikel, } \\
\text { pronomina, preposisi) }\end{array}$ \\
\hline & & 14- & p Baik $^{\text {Cuku }}$ & $\begin{array}{l}\text { Konstruksi } \text { sederhana } \\
\text { namun efektif, terdapat kesalahan } \\
\text { kecil pada konstruksi kompleks } \\
\text { terjadi sejumlah kesalahan } \\
\text { penggunaan bahasa (fungsi/ } \\
\text { urutan kata, artikel pronomina, } \\
\text { preposisi) namun makna cukup } \\
\text { jelas }\end{array}$ \\
\hline & & $10-$ & $\begin{array}{l}\text { Seda } \\
\text { ng-Cukup }\end{array}$ & \begin{tabular}{lrr}
\multicolumn{1}{c}{ Terjadi } & kesalahan & serius \\
dalam konstruksi kalimat & tunggal/ \\
kompleks & (sering & terjadi \\
kesalahan pada kalimat & negasi, \\
urutan/fungsi & kata, artikel, \\
pronomina, kalimat & fragmen,
\end{tabular} \\
\hline
\end{tabular}




\begin{tabular}{|c|c|c|c|c|}
\hline \multirow[t]{3}{*}{0} & \multirow[t]{3}{*}{\begin{tabular}{|l} 
Aspek \\
Penilaian
\end{tabular}} & $\begin{array}{r}\text { Ren } \\
\text { tang Skor }\end{array}$ & gori & Deskripsi \\
\hline & & & & $\begin{array}{l}\text { pelesapan, makna mem- } \\
\text { bingungkan atau kabur }\end{array}$ \\
\hline & & $7-9$ & $\begin{array}{l}\text { Sang } \\
\text { at Kurang }\end{array}$ & $\begin{array}{l}\text { Tidak } \\
\text { kalimat, terdapat } \\
\text { kesalahan, tidak komunikatif, } \\
\text { tidak layak dinilai }\end{array}$ \\
\hline & \multirow[t]{4}{*}{ Mekani } & 10 & $\begin{array}{l}\text { Sang } \\
\text { at Baik }\end{array}$ & 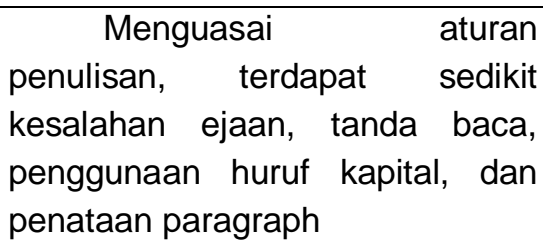 \\
\hline & & 6 & p Baik & $\begin{array}{l}\text { Kadang-kadang terjadi } \\
\text { kesalahan ejaan, tanda baca, } \\
\text { penggunaan huruf kapital, dan } \\
\text { penataan paragraf, namun tidak } \\
\text { mengaburkan makna }\end{array}$ \\
\hline & & 4 & $\begin{array}{l}\text { Seda } \\
\text { ng Cukup }\end{array}$ & $\begin{array}{l}\text { Sering terjadi kesalahan } \\
\text { ejaan, tanda baca, penggunaan } \\
\text { huruf kapital, dan penataan } \\
\text { paragraf, tulisan tangan tidak } \\
\text { jelas, } \\
\text { membingungkan/kabur makna }\end{array}$ \\
\hline & & 2 & $\begin{array}{l}\text { Sangat } \\
\text { Kurang }\end{array}$ & $\begin{array}{l}\text { Tidak menguasai aturan } \\
\text { penulisan, terdapat banyak } \\
\text { kesalahan ejaan, tanda baca, } \\
\text { penggunaan huruf kapital, dan } \\
\text { penataan paragraf, tulisan tidak } \\
\text { terbaca, tidak layak dinilai }\end{array}$ \\
\hline
\end{tabular}

Semua data yang diperoleh kemudian dianalisis sesuai dengan jenis data, baik dari hasil penilaian menulis teks diskusi, maupun penilaian hasil observasi siswa dan observasi guru. Setelah data dianalisis kemudian direfleksi untuk mendapatkan kesimpulan.

Data yang diperoleh dari siklus pertama dan kedua berupa skor dijumlahkan dan diubah menjadi kuantitatif. Adapun indikator keberhasilan penelitian ini dalam meningkatkan kemampuan menulis teks diskusi siswa dengan model pembelajaran kooperatif learning tipe debat, meliputi: (1) secara induvidual siswa memperoleh nilai minimal 70 , (2) secara klasikal $80 \%$ siswa mencapai nilai 70 ke atas, (3) nilai rata-rata kelas adalah 70 ke atas, dan (4) minimal siswa memiliki kategori nilai 70 dari respon pada aktivitas pembelajaran.

\section{HASIL DAN PEMBAHASAN}

Observasi Aktivitas Guru dan Siswa

Pengamatan atau observasi terhadap aktivitas guru dan siswa dilakukan pada setiap siklus. Pengamatan terhadap aktivitas guru dilakukan selama proses pembelajaran berlangsung, mulai dari kegiatan pendahuluan, kegiatan inti, sampai pada kegiatan penutup. Untuk lebih jelasnya dapat dilihat pada tabel berikut: 
Tabel 3

Hasil Penilaian Aktivitas Guru

\begin{tabular}{|c|c|c|c|c|c|}
\hline \multirow[b]{2}{*}{0} & Penga & \multicolumn{2}{|c|}{ Siklus I } & \multicolumn{2}{|c|}{ Siklus II } \\
\hline & mat & Nilai & Katego & Nilai & Kategori \\
\hline . & mat 1 Penga & 86,96 & Baik ${ }^{\text {Sangat }}$ & 89,1 & Baik \\
\hline 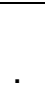 & mat 2 Penga & 87,78 & $\begin{array}{l}\text { Sangat } \\
\text { Baik }\end{array}$ & 91,3 & Sangat \\
\hline & $\begin{array}{ll}\text { Rata- } & \text { Rata } \\
\end{array}$ & 85,87 & $\begin{array}{l}\text { Sangat } \\
\text { Baik }\end{array}$ & 92,2 & Baik \\
\hline
\end{tabular}

Aktivitas guru dalam pembelajaran pada siklus I mencapai nilai rata-rata $85,87 \%$ dengan kategori penilaian sangat baik.Guru sudah melaksanakan pembelajaran sesuai dengan yang telah direncanakan. Namun masih ada beberapa orang siswa yang belum maksimal mengikuti proses pembelajaran, karena dalam kegiatan pembelajaran masih ada beberapa orang siswa yang belum terfokus perhatiaan dan partisipasinya, bahkan dalam menulis teks diskusi pun siswa belum begitu teliti mengerjakannya. Ini berarti guru belum maksimal dalam melaksanakan proses pembelajaran. Begitu pula pada siklus IIPengamatan terhadap aktivitas guru dalam pembelajaran dilakukan pada setiap pertemuan. Aktivitas guru pada siklus II mencapai nilai rata-rata 92,22\% dengan kategori sangat baik.

Sedangkan pengamatan terhadap aktivitas siswa pada pembelajaran dapat dilihat pada tabel berikut:

Tabel 4

Hasil Penilaian Observasi Siswa

\begin{tabular}{|c|c|c|c|}
\hline \multirow[b]{2}{*}{0} & \multirow[b]{2}{*}{ Aspek yang diamati } & \multicolumn{2}{|c|}{ Rata-rata Skor } \\
\hline & & s| Sikl & Siklis \\
\hline & $\begin{array}{l}\text { Perhatian mengikuti } \text { proses } \\
\text { pembelajaran }\end{array}$ & $52 \%$ & 93,63 \\
\hline & \begin{tabular}{l}
\multicolumn{1}{c}{ Aktif menaggapi argumen } \\
mendukung dan \\
debat/diskusi dengan santun
\end{tabular} & $52 \%$ & 86,27 \\
\hline & $\begin{array}{cccc}\text { Aktif } & \text { bekerja } & \text { sama } & \text { dalam } \\
\text { kelompoknya } & & & \\
\end{array}$ & $33 \%$ & 97,06 \\
\hline & $\begin{array}{l}\text { Teliti menulis teks diskusi atau tugas } \\
\text { yang diberikan oleh guru }\end{array}$ & $52 \%$ & 82,35 \\
\hline & Jumlah & $98 \%$ & 89,83 \\
\hline
\end{tabular}

Berdasarkan tabel di atas, terlihat bahwa ada peningkatan aktivitas siswa dari siklus I ke siklus II. Pada siklus I perhatian siswa mengikuti prses pembelajaran sebesar $79,52 \%$, meningkat menjadi 93,63\% pada siklus II. Selanjutnya aktivitas siswa bekerja sama dalam kelompoknya masing-masing meningkat dari $73,33 \%$ pada siklus I menjadi $97,06 \%$ pada siklus II. Hal ini memperlihatkan bahwa siswa makin tertarik mengikuti pembelajaran dengan model kooperatif learning tipe debat, apalagi mereka duduk berhadapan antar kelompok pro dan kontra dengan materi debat yang menarik perhatian mereka. Kemudian aktiftivitas siswa menaggapi argumen dalam debat juga mengalami 
peningkatan dari $69,52 \%$ pada siklus I menjadi $86,27 \%$ pada siklus II. Sedangkan aktivitas ketelitian siswa dalam menulis teks diskusi atau tugas yang diberikan oleh gurumeningkat dari siklus I sebesar 69,52\% meningkat menjadi 82,35\%. Dari kegiatan menanggapi argumen dalam debat pada aktivitas kedua berdampak pula pada hasil siswa dalam menulis teks diskusi, ini menandakan keterampilan siswa menulis teks diskusi sudah mengalami peningkatan.

\section{Hasil Tes Menulis Teks Diskusi}

Pelaksanaanpembelajaran pada siklus I dan siklus II sudah dilakukan secara optimal. Berdasarkan hasil observasi dan hasil penilaian menulis teks diskusi dengan menggunakan model kooperatif learning tipe debat, dapat dilihat padatabel berikut:

Tabel 5

Hasil Menulis Teks Diskusi

\begin{tabular}{|l|c|c|c|}
\hline 0 & Uraian & Siklus I & Siklus II \\
\hline. & Nilai Tertinggi & 80,67 & 89,00 \\
\hline. & Nilai Terendah & 53,67 & 65,00 \\
\hline. & Nilai rata-rata & 68,59 & 77,74 \\
\hline. & Ketuntasan Klasikal & $45,71 \%$ & $82,35 \%$ \\
\hline & Katergori Ketuntasan & Cukup & Baik \\
\hline
\end{tabular}

Dari tabel di atas terlihat bahwa pada siklus I, ketuntasan belajar klasikal siswa adalah $45,71 \%$. dari $80 \%$ yang direncanakan. Nilai tertinggi yang diperoleh siswa adalah 80,67 sedangkan nilai terendah 53,67 dengan nilai rata-rata 68,59 dari nilai minimal 70 yang direncanakan dan berkategori cukup. Dengan demikian dapat disimpulkan bahwa kemampuan siswa dalam menulis teks diskusi masih rendah.Dari identifikasi permasalahan yang ditemukan, ternyata siswa masih kurang teliti dalam menulis teks diskusi. Argumen yang dibuat siswa belum disertai data yang akurat untuk memperkuat argumennya, namun secara umum, ada beberapa hal yang telah dicapai pada siklus I ini yaitu:

Guru sudah menerapkan model pembelajaran kooperatif learning tipe debat dalam proses pembelajaran dan mulai menarik perhatian siswa.

Siswa aktif bekerja sama dalam kelompoknya dan perhatian pula dalam mengikuti pembelajaran.

Siswa sudah mulai berani dan aktif menanggapi dan menyampaikan argumen ketika debat berlangsung.

Nilai rata-rata kegiatan menulis teks diskusi yang diperoleh dari adalah 68,59 dengan kategori cukup.

Oleh karena itu, perlu memperbaiki proses pembelajaran pada siklus II agar siswa dapat menulis teks diskusi dengan lancar disertai dengan data yang akurat. Untuk mencapai hal tersebut ada beberapa hal yang perlu dilakukan guru pada siklus II yaitu:

Guru harus lebih mempersiapkan materi dangan penggunaan model kooperatif learning tipe debat dengan matang, serta meyakinkan siswa agar benar-benar siap menerima pembelajaran yang menggunakan model pembelajaran kooperatif learning tipe debat. 
Memberikan motivasi agar siswa lebih teliti dan aktif lagi dalam memberikan tanggapan yang disertai data dan fakta yang akurat untuk memperkuat pendapat yang disampaikan.

Guru memperlihatkan hasil pekerjaan siswa pada siklus I dan meminta siswa menanggapi hasil pekerjannya tersebut, sehingga siswa menemukan kekeliruannya dalam menulis teks diskusi.

Untuk mencapai tingkat keberhasilan yang lebih baik lagi, penelitian perlu dilanjutkan pada siklus II. Pada siklus II diperoleh data bahwa ketuntasan belajar klasikal $82,35 \%$. Nilai tertinggi yang diperoleh siswa adalah 89,00 sedangkan nilai terendah 65,00 dengan nilai rata-rata sebesar 77,74 berkategori baik. Dengan demikian dapat disimpulkan bahwa kemampuan siswa dalam menulis teks diskusi mengalami peningkatan dari kategori cukup pada siklus I menjadi baik pada siklus II.Berdasarkan data di atas ada peningkatan nilai menulis teks diskusi siswa dari siklus I ke siklus II. Untuk nilai tertinggi mengalami peningkatan dari nilai 80,67 pada siklus I meningkat menjadi 89,00 pada siklus II. Selanjutnya nilai terendah pada sisklus I adalah 53,67 mengalami peningkatan menjadi 65,00 pada siklus II. Sedangkan nilai rata-ratanya juga mengalami peningkatan dari siklus I ke siklus II, yaitu dari 45,59 pada siklus I meningkat menjadi 77,74 pada siklus II.Oleh karena itu, dapat dikatakan bahwa tindakan pada siklus II sudah mencapai kriteria keberhasilan yang telah ditetapkan, Ini berarti indikator keberhasilan sudah tercapai sehingga penelitian tidak dilanjutkan pada siklus berikutnya.

\section{Pembahasan}

Model pembelajaran kooperatif learning tipe debat dalam upaya meningkatkan kemampuan siswa dalam menulis teks diskusi, serta aktivitas yang dilakukan oleh guru dan siswa dalam penelitian ini sudah dideskripsikan dengan jelas. Ini merupakan gambaran secara umum tentang kegiatan pembelajaran yang menggunakan model pembelajaran kooperatif learning tipe debat. Guru sudah berusaha menerapkan model pembelajaran ini dengan baik. Hal ini dapat dilihat dari hasil observasi aktivitas guru selama proses pembelajaran berlangsung. Pada siklus I skor yang diperoleh guru adalah $85,87 \%$ dengan kategori baik. Pada siklus ini masih adasiswa yang belum aktif mengikuti proses pembelajaran, terutama ketika debat berlangsung. Namun pada siklus II guru lebih dapat mengelola kelas dengan lebih baik lagi, hal ini dapat pada skor yang diperoleh guru pada siklus ini II adalah $89,83 \%$ dengan kategori sangat baik.

Pembelajaran yang dilakukan oleh guru dalam menerapkan model pembelajaran kooperatif learning tipe debat, pada siklus I sampai pada siklus II sudah memberikan kesempatan kepada siswa untuk membuat argumen yang disertai dengan bukti/data, fakta akurat, pengalaman penulis serta referensi yang berhubungan dengan isu yang dibahas. Selain itu, arguman mendukung dan menentang yang dibuat siswa dalam menulis teks diskusi, sudah dapat dipahami dengan jelas dan ini menandakan model pembelajaran kooperatif learning tipe debat dapat memudahkan siswa dalam menulis teks diskusi yang baik.

Aktivitas siswa dalam mengikuti pembelajarn juga mengalami peningkatan yang signifikan pada kedua siklus yang dilakukan. Aktivitas perhatian siswa pada proses pembelajaran siklus I sebesar $79,52 \%$, mengalamipeningkatan sampai pelaksanaan siklus II yaitu 93,63\%.Kemudian aktivitas siswa dalam menanggapi argumen dalam debat/diskusi dengan santun adalah $69,52 \%$ pada siklus I juga mengalami peningkatan pada siklus II sebesar $86,27 \%$. Selanjutnya penilaian terhadap aktivitas siswa dalam bekerja sama dalam kelompoknya masing-masing pada siklus I sebesar 73,34 \%, pada siklus II terjadi peningkatan yaitu sebesar $97,06 \%$. Terakhir pada aktivitas ketelitian dalam menulis teks diskusi atau tugas yang diberikan oleh guru pada siklus I adalah $69,52 \%$ mengalami peningkatan pada siklus II yaitu $82,35 \%$.

Guru sudah berupaya semaksimal mungkin dalam meningkatkan kemampuan siswa menulis teks diskusi dengan model pembelajaran kooperatif learning tipe debat pada siswa kelas VIII H SMP Negeri 1 Rejang Lebong. Hal ini dapat dilihat dari hasil pembelajaran selama dua siklus yang terus mengalami peningkatan. Berdasarkan data yang diperoleh dari tim peneliti, diketahui bahwa 
kemampuan siswa dalam menulis teks diskusi mengalami peningkatan dari siklus I sampai pada siklus II. Pada siklus 1 sebanyak 16 orang siswa mendapat nilai $\geq 70$ dan 19 orang siswa mendapat nilai $\leq 70$ dengan ketuntasan belajar klasikal $45,71 \%$. Nilai tertinggi yang diperoleh siswa adalah 80,67 sedangkan nilai terendah 53,67 dengan nilai rata-ratasebesar 68,59 . Selain itu, berdasarkan hasil analisis kemampuan siswa dalam menulis teks diskusi pada siklus 1 , ada dua orang siswa mendapat nilai sangat baik, 14 orang siswa memperoleh nilai dengan kategori baik, 17 orang siswa memperoleh nilai dengan kategori cukup, dan 2 orang siswa dengan nilai kategori kurang. Dengan demikian dapat disimpulkan bahwa kemampuan siswa menulis teks diskusi pada siklus I ini masih rendah dan perlu dilanjutkan pada siklus II.

Selanjutnya ada siklus II sebanyak 28 orang siswa memperoleh nilai $\geq 70$ dan 6 orang siswa memperoleh nilai $\leq 70$ dengan ketuntasan belajar klasikal $82,35 \%$. Nilai tertinggi yang diperoleh siswa adalah 89,00 sedangkan nilai terendah 65,00 dengan nilai rata-rata sebesar $82,35 \%$. Berdasarkan analisis kemampuan menulis teks diskusi pada siklus II ini juga dapat dilihat bahwa 15 orang siswa memperoleh nilai dengan kategori sangat baik 13 orang siswa memperoleh nilai dengan kategori baik, 6 orang siswa memperoleh nilai dengan kategori cukup, serta ada satu orang siswa yang tidak masuk ketika pembelejaran berlangsung karena sakit. Dengan demikian dapat disimpulkan bahwa kemampuan siswa dalam menulis teks diskusi sudah mengalami peningkatan dari kategori cukup pada siklus I menjadi kategori Baik pada siklus II.

Selanjutnya, setalah kegiatan pembelajaran berlangsung perolehan nilai siswa dalam menulis teks diskusi juga mengalami kenaikan pada setiap siklusnya. Nilai tertinggi siklus I yaitu 86 meningkat menjadi 90 pada siklus II. Sedangkan nilai terendah pada siklus I adalah 80,67, meningkat menjadi 89,00 pada siklus II. Kemudian nilai rata-rata dan ketuntasan klasikal juga mengalami peningkatan yang signifikan. Pada siklus I jumlah nilai rata-rata yang diperoleh siswa dalam menulis teks diskusi adalah 68,59 dengan ketuntasan klasikal $45,71 \%$. Angka ini mengalami peningkatan pada siklus II yaitu $77,74 \%$ untuk nilai rata-rata dan ketuntasan klasikal menjadi $82,35 \%$.

Dari hasil belajar siswa menunjukkan bahwa dengan model pembelajaran kooperatif learning tipe debat dapat meningkatkan kemampuan siswa dalam menulis teks diskusi. Dengan demikian, dari hasil observasi aktivitas guru dan siswa serta, menunjukkan adaya peningkatan mulai dari siklus I sampai siklus II. Peningkatan ini terlihat dari sebagian besar siswa sudah dapat menulis teks diskusi dengan stuktur yang benar, disertai dengan argumen mendukung dan argumen menentang yang diikuti dengan data-fakta yang akurat untuk memperkuat argumen. Selain itu, aktivitas siswa dalam mengikuti proses pembelajaran juga mengalami peningkatan. Gambaran ini menunjukkan bahwa model pembelajaran kooperatif learning tipe debat mampu meningkatkan kemampuan siswa dalam menulis teks diskusi.

\section{PENUTUP}

Berdasarkan hasil penelitian dan pembahasan dapat disimpulkan bahwa kemampuan siswa dalam menulis teks diskusi dengan menggunakan model pembelajaran kooperatif learning tipe debat pada siswa kelas VIII H SMP Negeri 1 Rejang Lebong, sudah terjadi peningkatan. Hal ini dapat dilihat dari hasil pembelajaran siklus I dengan nilai rata-rata 68,59 dengan kategori cukup, dan ketuntasan klasikal 47,51. Kemudian meningkat pada siklus II dengan rata-rata 77,74 dengan kategori baik dan keuntasan klasikal 82,35.

Melalui model pembelajaran kooperatif learning tipe debat memudahkan siswa menyampaikan argumen yang didukung oleh bukti/data, fakta akurat, pengalaman penulis serta referensi yang berhubungan dengan isu yang dibahas. Sehingga teks diskusi yang dibuat siswa mudah dipahami karena model pembelajaran yang digunakan dalam proses pembelajaran menarik minat dan memudahkan siswa menulis teks diskusi.

Guru dapat menggunakan model pembelajaran kooperatif lerning tipe debat dalam proses pembelajaran untuk meningkatkan kemampuan siswa dalam menulis, khususnya menulis teks diskusi. 


\section{DAFTAR PUSTAKA}

Arikunto, Suharsimi. 2006. Prosedur Penelitian Suatu Pendekatan Praktik. Jakarta: Rineka Cipta.

Komalasari, Kokom. 2011. Pembelajaran Kontekstual: Konsep dan Aplikasi. Bandung: Refika Aditama.

Kusmana, Suherli. 2010. Guru Bahasa Indonesia Profesional. Jakarta: Sketsa Aksara Lalitya.

Mulyasa. 2009. Praktik Penelitian Tindakan Kelas. Bandung: PT Remaja Rosdakarya.

Nurgiyantoro, Burhan. 1988. Penilaian dalam Pengajaran Bahasa dan Sastra Indonesia. Yogyakarta: BPFE.

Saddhono, Kundharu dan Slamet.Y. 2012. Meningkatkan Keterampilan Berbahasa Indonesia. Bandung: CV Karya Putra Darwanti.

Saddhono, Kundharu dan Slamet. 2014. Pembelajaran keterampilan Berbahasa Indonesia Teori dan Aplikasi. Yogyakarta: Graha IImu.

Sanjaya, Wina. 2009. Penelitian Tindakan Kelas. Jakarta: Kencana Prenada Media Group.

Shoimin, Aris. 2014. 68 Model Pembelajaran dalam Kurikulum 2013. Ar Ruzzmia.

Slamet, Y dan Kandaru Saddhono. 2012. Meningkatkan Keterampilan Berbahasa Indonesia. Bandung; CV Karya Putra Darwanti.

Suprijono, Agus: Cooperative Learning: Teori dan Aplikasi Paikem. Yogyakarta: Pustaka Pelajar.

Susetyo. 2009. Menulis Akademik. Bengkulu: Unit Penerbitan FKIP UNIB.

Suyanto dan Asep Jihad. 2014. Cara Cepat Belajar Menulis Karya Ilmiah. Yogyakarta: Multi Pressindo.

Taigan. Henry Guntur. 1982. Menulis Sebagai Suatu Keterampilan Berbahasa. Bandung: Angkasa Badung.

Amri, Al Habib Sholihul . 2017.Teks Diskusi. http://ensiklopediasli.blogspot. co.id/2017/04/teksdiskusi. html. Diakses [07 Maret 2017].

Badriyahs, Siti. 2015.http://blogbadriyahs.Blogspot.co.id/2015/12/ Model pembelajaran Debate. html 04 Mei 2017 siti badriah. Diakses [07 Maret 2017] 